\title{
FIRST RECORD OF THE PARASITIC GAMASID MITE SPINTURNIX EMARGINATUS (KOLENATI, 1856) IN CRIMEA
}

\author{
Maria V. Orlova ${ }^{1,2^{*}}$ and Oleg L. Orlov ${ }^{2,3}$
}

\author{
${ }^{1}$ Tomsk State University, Tomsk, Russia \\ ${ }^{2}$ Tyumen State University, Tyumen, Russia \\ ${ }^{3}$ Ural Medical State University, Russia \\ *corresponding author; e-mail: masha_orlova@mail.ru
}

\begin{abstract}
Spinturnix emarginatus (Kolenati, 1856) (Mesostigmata: Gamasina: Spinturnicidae), collected from Geoffroy's bats
\end{abstract} Myotis emarginatus (E. Geoffroy, 1806) (Chiroptera: Vespertilionidae), is reported from Crimea for the first time.

KEY WORDS: Bat gamasid mite, Spinturnix emarginatus, Spinturnicidae, Myotis emarginatus.

DOI: 10.21684/0132-8077-2018-26-2-237-242

\section{INTRODUCTION}

Myotis emarginatus (E. Geoffroy, 1806) (Chiroptera: Vespertilionidae) occurs in several places: southern Europe (from Portugal in the west to the Balkans in the east); in the southern parts of western and central Europe; and in non-arid parts of southwestern Asia. The latter category includes Asia Minor, the Caucasus, Palestine, Oman, Uzbekistan and Tajikistan. This species has also been reported from northwest Africa (northern Maghreb: Algeria, Morocco and Tunisia). The species is protected by national legislation in most of the above mentioned range states. There is also an international legal liability for its protection under the Bonn (Eurobats) and the Bern Conventions (in the range states where these apply). In addition, Geoffroy's bat is included in the Annex IV of EU Habitats and Species Directive. There is some habitat protection through the Natura 2000 network as well (Piraccini 2016). In southern Crimea, where Geoffroy's bat is a rare species, its parasite fauna is of particular interest.

Spinturnicid mites are specific bat ectoparasites, almost exclusively found on wings and tail membranes. Recent studies undertaken in many parts of the world have resulted in isolating a number of pathogenic microorganisms from spinturnicid mites, such as Bartonella sp., Rickettsia sp. and Anaplasma sp. (Reeves et al. 2006, 2016; SzubertKruszynska et al. 2009).

Previously, four species belonging to the genus Spinturnix were reported from the territory of Crimea: S. myoti (Kolenati, 1856); S. kolenatii Oudemans, 1910; S. acuminatus (C.L. Koch, 1836); and S. helvetiae (Deunff, Keller et Aellen, 1986) (Stanyukovich 1997).

\section{MATERIAL AND METHODS}

Bats were caught using mist nets in the Vyazemskiy Karadag Research Station reserve (44 $56^{\prime} \mathrm{N} 35^{\circ} 14^{\prime}$ E), on 26 July 2017, leg. O.L. Orlov and A.V. Ivanitskiy. After examination, all the bats were released. Ectoparasites were removed with a preparatory needle and forceps and were fixed in $70 \%$ ethanol. The mites were mounted on permanent slides with Faure-Berlese's mounting medium (Whitaker 1988). Photographs were taken with a digital camera AxioCam ICc5 (Zeiss, Germany) via a compound microscope AxioImager A2 (Zeiss, Germany) with a phase-contrast and DIC objectives. All the collected specimens are deposited in the collection of the Tyumen State University Museum of Zoology (Tyumen, Russia).

\section{RESULTS AND DISCUSSION}

Spinturnix emarginatus is a specific ectoparasite of Geoffroy's bat Myotis emarginatus.

Material. A total of 5 specimens of $S$. emarginatus ( 2 + 9 , $\widehat{\jmath}$, NI, NII) (Figs. 1-5) were collected from 2 individuals of M. emarginatus. All of the specimens were obtained from the wings.

Distribution. So far, findings of S. emarginatus have been scarce and geographically dispersed. In particular, single records are known from Bulgaria, the Czech Republic (Dusbábek 1964), Hungary (Beron 1965), France (Deunff 1977), Spain (Peribañez-Lopez et al. 1989), Tajikistan (Stanyukovich 1997), Poland, Slovakia (Krištofik et al. 2012) and Serbia (Burazerović et al. 2017).

Measurements of the collected specimens are provided in the Table 1 below. 


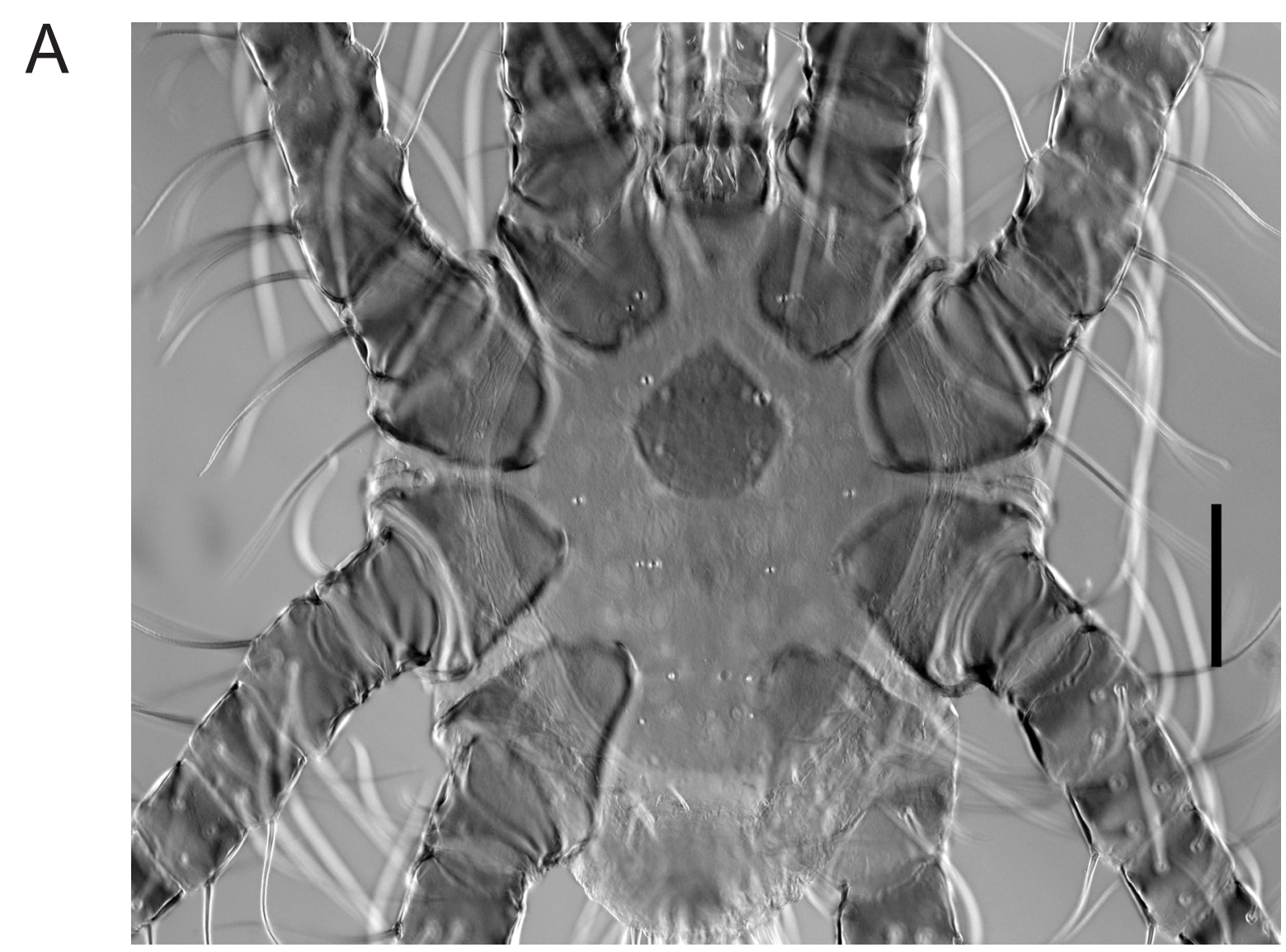

B

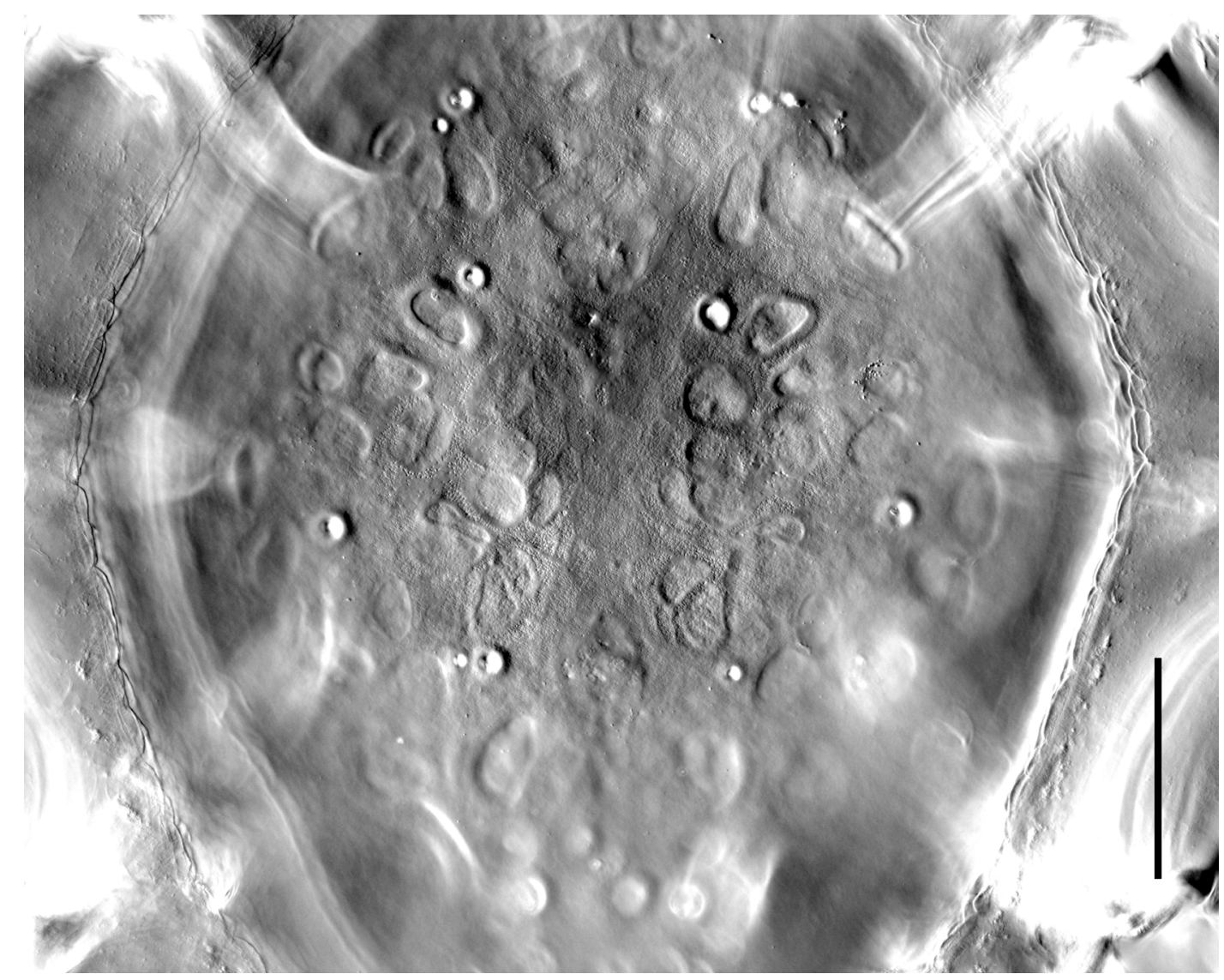

Fig. 1. Spinturnix emarginatus: A——, dorsal idiosoma, scale bar $=200 \mu \mathrm{m} ; \mathrm{B} — \uparrow$, pitted surface of dorsal shield, scale bar $=100 \mu \mathrm{m}$. 
First record of Spinturnix emarginatus in Crimea

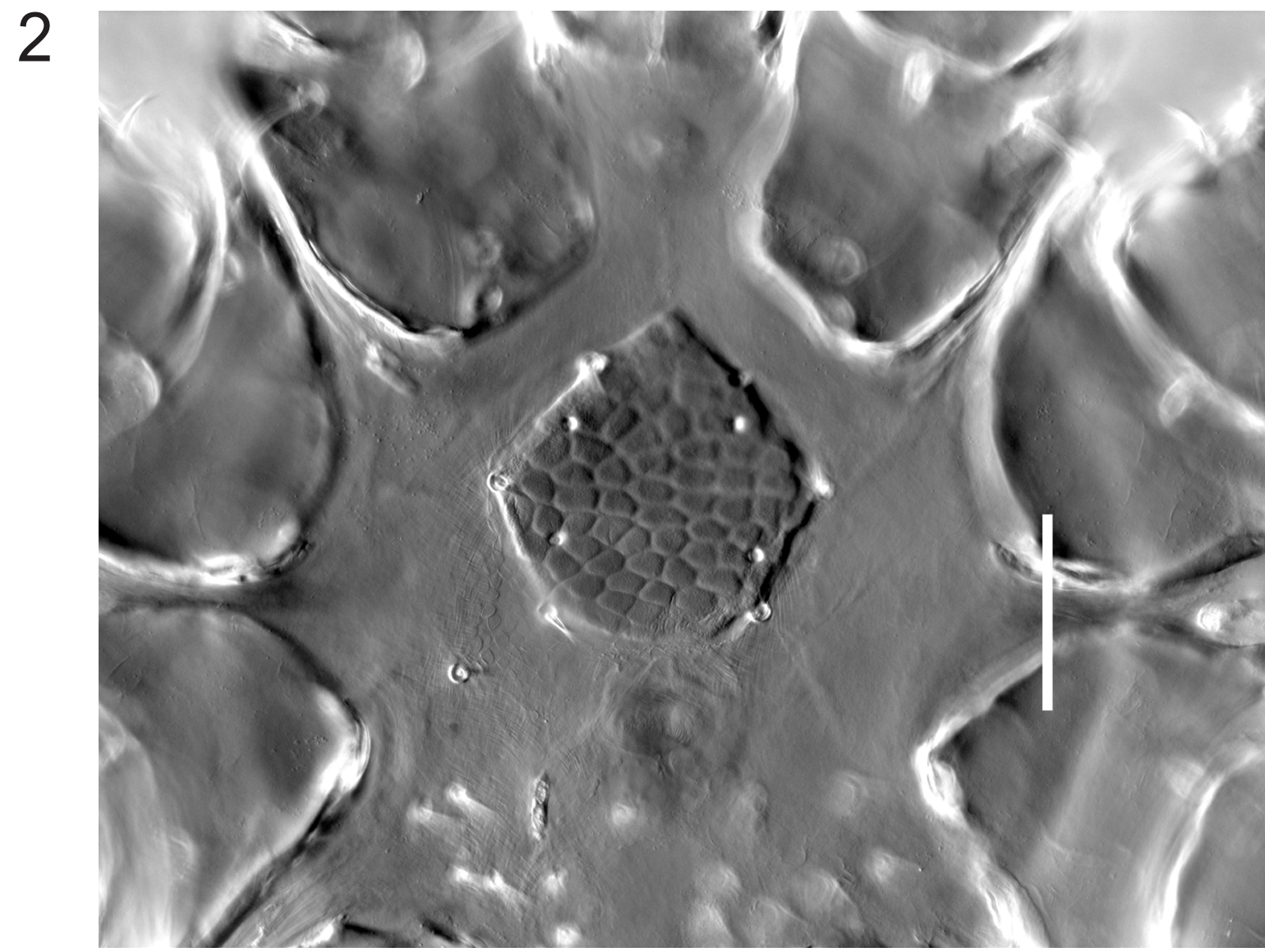

\section{3}

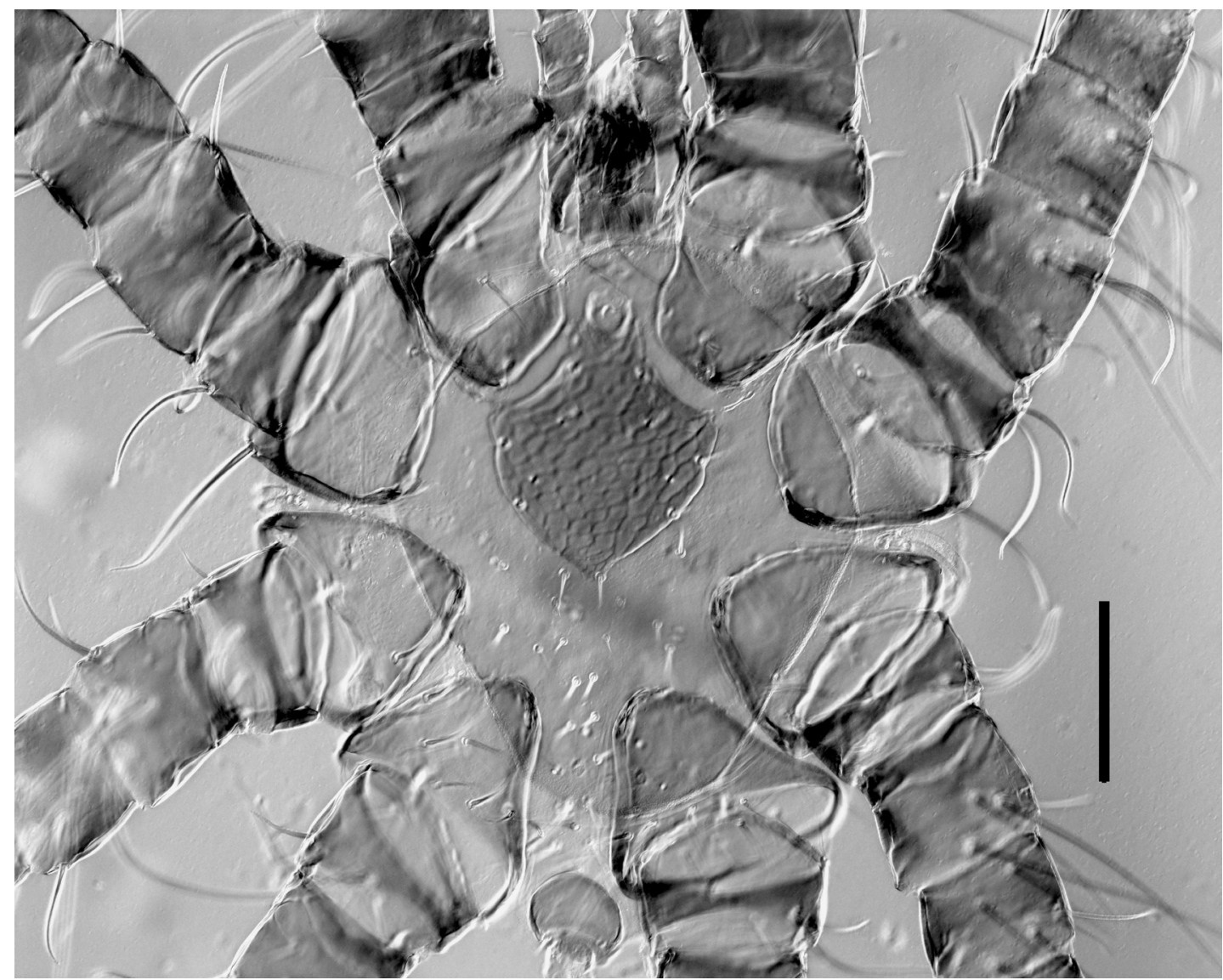

Figs. 2, 3. Spinturnix emarginatus: $2-+$, sternal shield, scale bar $=100 \mu \mathrm{m} ; 3-\hat{0}$, dorsal idiosoma, scale bar $=200 \mu \mathrm{m}$. 
M.V. Orlova and O.L. Orlov

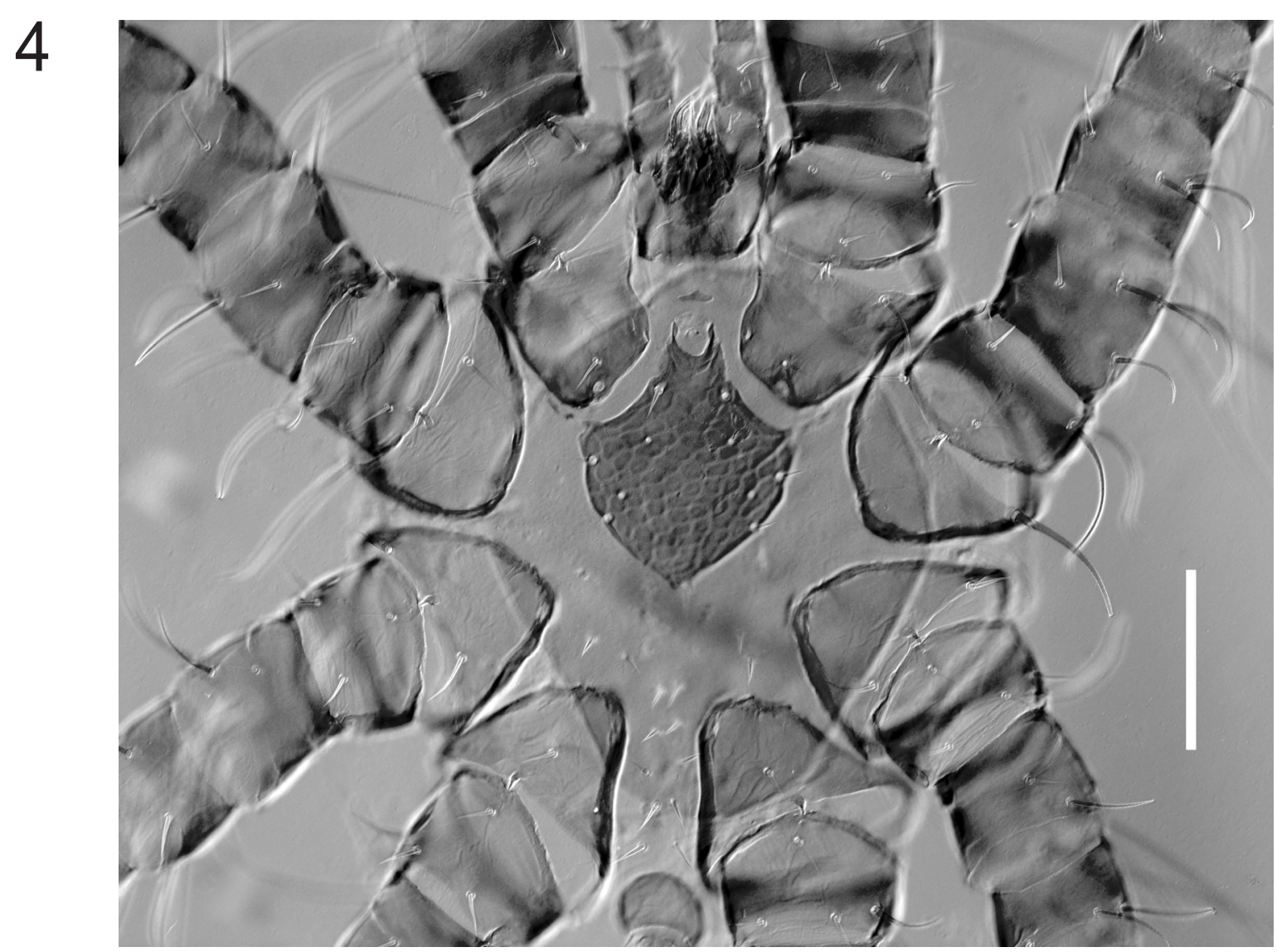

5

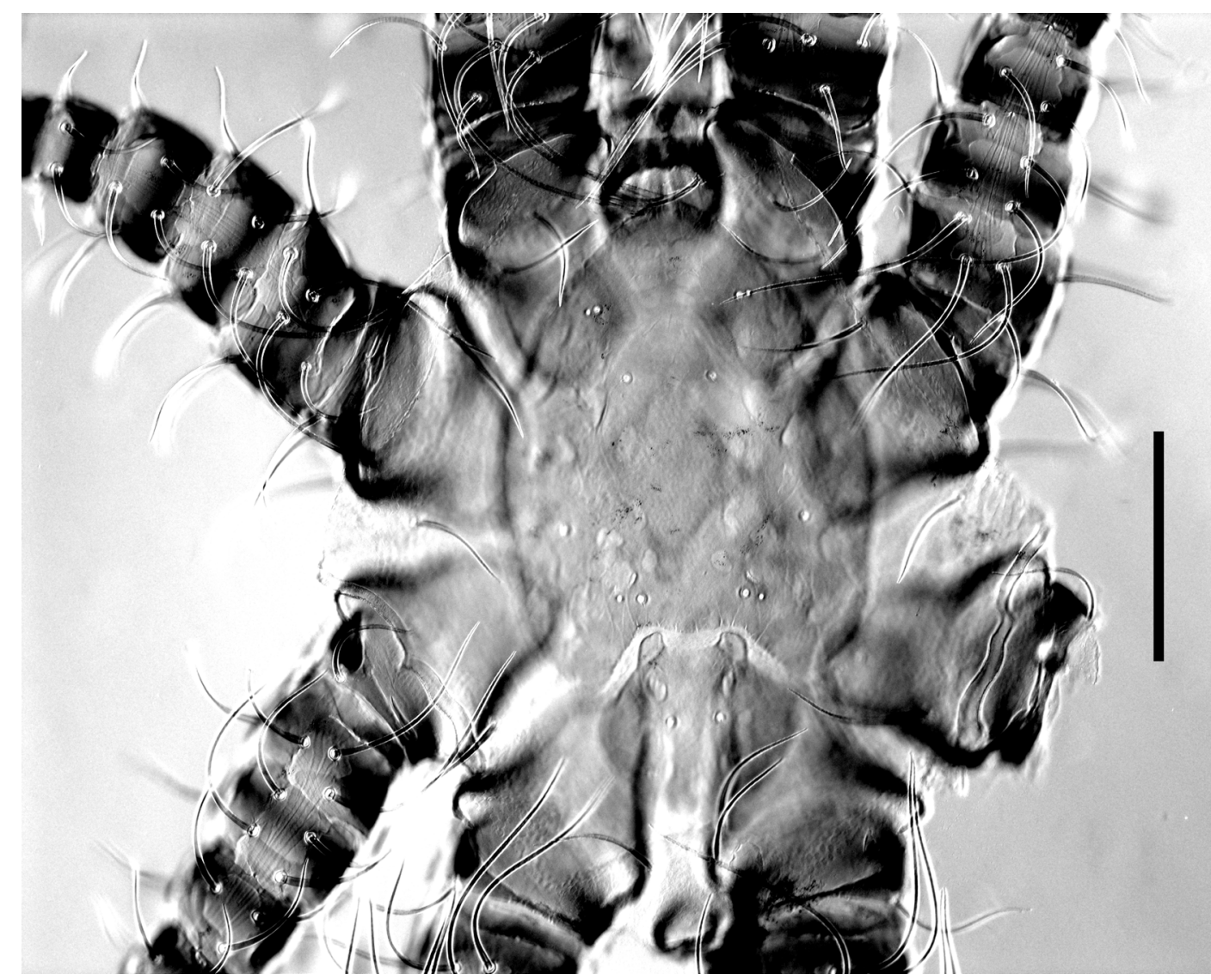

Fig. 4, 5. Spinturnix emarginatus: 4- $\hat{0}$, sternal shield, scale bar $=200 \mu \mathrm{m} ; 5$-protonymph, dorsal idiosoma, scale bar $=200 \mu \mathrm{m}$. 
Table 1.

Comparison of body part measurements of Spinturnix emarginatus from Crimea and Poland.

\begin{tabular}{|c|c|c|c|c|}
\hline Stage & Body part & Length, $\mu \mathrm{m}$ & Width, $\mu \mathrm{m}$ & References \\
\hline \multirow{6}{*}{ Female } & \multirow{2}{*}{ Idiosoma } & 885,909 & 722,734 & Crimea, own data $(\mathrm{n}=2)$ \\
\hline & & $1075-1142$ & $940-1015$ & Poland, Krištofik et al. 2012 \\
\hline & \multirow{2}{*}{ Dorsal shield } & 623,630 & 484,498 & Crimea, own data $(\mathrm{n}=2)$ \\
\hline & & $584-638$ & $491-518$ & Poland, Krištofik et al. 2012 \\
\hline & \multirow{2}{*}{ Sternal shield } & 156,174 & 169,184 & Crimea, own data $(\mathrm{n}=2)$ \\
\hline & & $181-188$ & $186-192$ & Poland, Krištofik et al. 2012 \\
\hline \multirow{6}{*}{ Male } & \multirow{2}{*}{ Idiosoma } & 904 & 726 & Crimea, own data $(\mathrm{n}=1)$ \\
\hline & & $846-851$ & $708-716$ & Poland, Krištofik et al. 2012 \\
\hline & \multirow{2}{*}{ Dorsal shield } & 592 & 481 & Crimea, own data $(\mathrm{n}=1)$ \\
\hline & & $545-572$ & $502-515$ & Poland, Krištofik et al. 2012 \\
\hline & \multirow{2}{*}{ Sternal shield } & 304 & 231 & Crimea, own data $(\mathrm{n}=1)$ \\
\hline & & $303-308$ & $238-242$ & Poland, Krištofik et al. 2012 \\
\hline \multirow{3}{*}{ Protonymph } & Idiosoma & 878 & 758 & \multirow{3}{*}{ Crimea, own data $(\mathrm{n}=1)$} \\
\hline & Podonotal shield & 452 & 380 & \\
\hline & Pigidial shield & 179 & 209 & \\
\hline
\end{tabular}

We believe that the bat ectoparasite fauna of Crimea has received insufficient attention. In addition to the Spinturnix species mentioned above, at least 5 Spinturnicid mite species have been recorded for the Western Palaearctic subregion. These species include S. plecotinus (C.L. Koch, 1839); $S$. punctata (Sundevall, 1833); S. nobleti Deunff, Volleth, Keller, Allen, 1990; S. psi (Kolenati, 1856); and S. mystacina (Kolenati, 1857). We can expect their presence in Crimea as well.

\section{ACKNOWLEDGEMENTS}

The authors are grateful to the administration of the Vyazemskiy Karadag Research Station reserve for their help with the field work.

\section{REFERENCES}

Beron P. 1965. Contribution à l'étude des Acaries parasites des chiroptères en Hongrie (Spinturnicidae, Trombiculidae, Myobiidae et Acaridae). Vertebrata Hungarica 7: 141-152.

Burazerović J., Orlova M., Obradović M., Ćirović D. and Tomanović S. 2018. Patterns of abundance and host specificity of bat ectoparasites in the Central Balkans. Journal of Medical Entomology, 55 (1): 20-28.
Deunff J. 1977. Observations sur les Spinturnicidae de la région Paléartique Occidentale (Acarina, Mesostigmata). Spécificité, répartition et morphologie. Acarologia, 18: 602-617.

Dusbábek F. 1964. Contribution à la connaissance des acariens (Acarina) parasites des chiropterès de Bulgarie. Acarologia, 6: 5-25.

Krištofík J., Piksa K. and Sachanowicz K. 2012. Two spinturnicid mites new to the fauna of Poland (Acari: Spinturnicidae). Polish Journal of Entomology, 81 (2): 101-106.

Peribañez-Lopez M.A., Sánchez-Acedo C. and EstradaPeña A. 1989. Estudio morfológico de los àcaros de la familia Spinturnicidae (Acarina, Gamasidae) del Norte y Levante español. Revista Ibérica de Parasitologia, 49: 357-373.

Piraccini, R. 2016. Myotis emarginatus. The IUCN Red List of Threatened Species 2016: e.T14129A2205 1191. DOI: 10.2305/IUCN.UK.2016-2.RLTS. T14129A22051191.en. https://www.iucnredlist.org/ species/14129/22051191. Downloaded on 26 December 2018.

Reeves W.K., Dowling A.P. and Dasch G.A. 2006. Rickettsial agents from parasitic dermanyssoidea (Acari: Mesostigmata). Experimental and Applied Acarology, 38 (2-3): 181-188. 
Reeves W.K., Beck J., Orlova M.V., Daly J.L., Pippin K., Revan F. and Loftis A.D. 2016. Ecology of bats, their ectoparasites, and associated pathogens on Saint Kitts Island. Journal of Medical Entomology, 53 (5): 1218-1225.

Stanyukovich M.K. 1997. Keys to the gamasid mites (Acari, Parasitiformes, Mesostigmata, Macronyssoidea et Laelaptoidea) parasiting bats (Mammalia, Chiroptera) from Russia and adjacent count- ries. Rudolstädter Naturhistorische Schriften. 7: $13-46$.

Szubert-Kruszyńska A., Michalik J., Stańczak J., Cieniuch S., Podsiadły E. 2009. Molecular survey of haematophagous spinturnicid mites (Acari: Spinturnicidae) and their bat host for rickettsial agents in Poland. In: X International Jena Symposium on Tick-Borne Diseases (19-21 March 2009, Weimar, Germany). Abstract Book. Weimar, vol. 14, p. 38. 